\title{
Effect of calcium phosphate addition on sintering of El-Oued sand quartz raw materials
}

\section{(Efeito da adição de fosfato de cálcio na sinterização de matérias-primas de quartzo da areia de El-Oued)}

\author{
L. Foughali, ${ }^{1,2}$, A. Harabi', J. P. Bonnet ${ }^{3}$, D. Smith ${ }^{3}$, B. Boudaira ${ }^{1}$ \\ ${ }^{1}$ Ceramics Lab., Physics Department, Faculty of Exact Science, Constantine University 1, Algeria \\ ${ }^{2}$ Material Science Department, Faculty of Exact and Naturell Science, Oum Elbouaghi University, Algeria \\ ${ }^{3}$ Ecole Nationale Superieure de Céramiques Industrièles, Limoges, France \\ foughali_lazhar@yahoo.fr
}

\begin{abstract}
This work addresses the development of an eventual low cost ceramic insulating or microfiltration membrane supports from inexpensive raw materials such Eloued quartz sand (EQS) and calcium phosphate (CP) using uniaxially dry compaction method. The prepared samples were sintered at different temperatures ranging between 1200 and $1550{ }^{\circ} \mathrm{C}$. Subsequently, the effects of sintering temperature and amount of $\mathrm{CP}$ on samples proprieties were investigated. It is observed that X-ray diffracion measurements confirmed that EQS was transformed into cristobalite and tridymite phases when both sintering temperature and holding time were increased. This transformation is favored with increasing amount of $\mathrm{CP}$, it is observed also formation of $\mathrm{CaSiO} \mathrm{O}_{3}$ and $\mathrm{Ca}(\mathrm{Fe})(\mathrm{Al})$ $\mathrm{PO}_{4}$. The SEM images of the samples sintered at different temperatures illustrate that silica grains, CP grains, intergranular phase contents ( $\mathrm{Si}, \mathrm{Ca}, \mathrm{P}$, and $\mathrm{O}$ ) and an important open porosity depend on the sintering temperature. The porosity ratio changes in the range between $37 \%$ and $34 \%$ according to sintering temperature and to CP content; these values are in good agreement with SEM images. The thermal expansion behavior shows a weak expansion in the range of temperature between 600 and $1000{ }^{\circ} \mathrm{C}$ which is situated between $1.27 \%$ and $1.33 \%$ (variation of $0.05 \%$ at $400{ }^{\circ} \mathrm{C}$ ).
\end{abstract}

Keywords: quartz sand, calcium phosphate, sintering, porosity, cristobalite.

Resumo

Este trabalho aborda o desenvolvimento de uma membrana cerâmica isolante ou de microfiltração eventualmente de baixo custo para matérias-primas de areia de quartzo Eloued (EQS) e fosfato de cálcio (CP) usando o método de compactação uniaxial a seco. As amostras preparadas foram sinterizadas em diferentes temperaturas entre 1200 e $1550{ }^{\circ} \mathrm{C}$. Subseqüentemente, foram investigados o efeito da temperatura de sinterização e a quantidade de CP nas propriedades das amostras. Análise de difração de raios $X$ confirmou que EQS foi transformada nas fases cristobalita e tridimita quando a temperatura de sinterização e o tempo de patamar foram aumentados. Essa transformação é favorecida com aumento da quantidade de CP, sendo observada também a formação de $\mathrm{CaSiO}_{3}$ and $\mathrm{Ca}(\mathrm{Fe})(\mathrm{Al}) \mathrm{PO}_{4}$. As imagens de microscopia eletrônica de varredura (MEV) das amostras sinterizadas em diferentes temperaturas mostram que os grãos de silica, grãos $\mathrm{CP}$, contendo fases intragranular de ( $\mathrm{Si}$, Ca, $\mathrm{P}$ e O) e uma considerável porosidade aberta dependem da temperatura de sinterização. A razão da porosidade varia entre $37 \%$ e $34 \%$ conforme a temperatura de sinterização e o teor CP; este valores estão de acordo com as imagens de MEV. O comportamento da expansão térmica mostra uma fraca expansão entre 600 e $1000{ }^{\circ} \mathrm{C}$, a qual está entre $1,27 \%$ e $1,33 \%$ (variando de $0,05 \%$ em $400{ }^{\circ} \mathrm{C}$ ).

Palavras-chave: areia de quartzo, fosfato de cálcio, sinterização, porosidade, cristobalita.

\section{INTRODUCTION}

Silica is a mineral used in many domains. The traditional view is that there are three distinct families of silica structures which are stable at ambient pressure: quartz, tridymite and cristobalite. Although quartz is believed to be the stable phase at temperatures below $870{ }^{\circ} \mathrm{C}$, both tridymite and cristobalite can be cooled to low temperatures, where they are metastable. The conversion of quartz into tridymite can be occurred at temperatures more than $870{ }^{\circ} \mathrm{C}$ with mineralizer. It seems besides that the temperature of transition depends on nature and concentrations of the mineralizer. The transformation of pure quartz, under the only action of the temperature, always leads to cristobalite formation. Theoretically, the temperature must exceed $870{ }^{\circ} \mathrm{C}$; practically it is generally necessary to reach $1000{ }^{\circ} \mathrm{C}$ to put into evidence the presence of cristobalite; and the speed of transformation increases with the sintering temperature. However, the cristobalite maintained at a temperature ranging between 870 and $1470{ }^{\circ} \mathrm{C}$ is transformed into stable tridymite in this temperature range; the transformation rate is always much smaller than that of quartz to cristobalite [1]. The 
use of silica in the form of bricks involves a sintering and a transformation of quartz to cristobalite and tridymite at higher temperatures. Foreign oxides additions may be used in order to promote this phase transformation [2]. This work deals with the effect of calcium phosphate (CP) raw material on the sintering and transformation of El-Oued sand quartz (ESQ) in order to prepare an eventual low cost ceramic microfiltration membrane supports or a thermal insulation material from inexpensive raw materials. In this way, Algeria is one of the countries in the world that have abundantly available raw materials. Mainly: calcite $\left(\mathrm{CaCO}_{3}\right)$, dolomite $\left(\mathrm{CaCO}_{3} \cdot \mathrm{MgCO}_{3}\right)$, bones (natural derived hydroxyapatite: HA $\left(\mathrm{Ca}_{10}\left(\mathrm{PO}_{4}\right)_{6}(\mathrm{OH})_{2}\right)$, kaolin, feldspar and quartz. Many works have already been published for valorizing these native raw materials. These topics concern advanced ceramics [3-9], ceramic membranes [10-16] and bioceramics [17-24].

\section{EXPERIMENTAL PROCEDURES}

The used raw materials are very rich sand crystalline silica as a quartz (Eloued sand, Algeria) and a calcium phosphate mineral (Bir Elater, Algeria) CP. Their chemical compositions in $\mathrm{wt} \%$ are given in Table I.

Fig. 1 shows a schematic drawing of the main steps of the samples preparation route, used in this work. Firstly, three mixtures were prepared; the first contains $90 \mathrm{wt} . \%$ EQS and 10 wt.\% CP whereas the second one contains 80 wt.\% EQS and $20 \mathrm{wt} . \% \mathrm{CP}$ and the third contains $70 \mathrm{wt} . \%$ EQS and 30 wt.\% CP. The materials were then ground with water in a planetary mill for $1 \mathrm{~h}$ and dried at 100 ${ }^{\circ} \mathrm{C}$. The mixtures are compacted in the form of discs (13 $\mathrm{mm}$ in diameter: and 5-6 $\mathrm{mm}$ in thickness) at $140 \mathrm{MPa}$. Subsequently, the compacted samples were fired for 2 and $4 \mathrm{~h}$ at temperatures ranged between 1200 and $1550{ }^{\circ} \mathrm{C}$ at a heating rate of about $5{ }^{\circ} \mathrm{C} / \mathrm{min}$.

The phase composition of samples was determined on a derived configuration equipments (INEL CPS120 curved position sensitive detector). Cuk $\alpha$ radiation was used at the operating condition of $40 \mathrm{kV}$ and $20 \mathrm{~mA}$. The XRD data was collected over the $2 \theta$ range of $15-70^{\circ}$ with a step size of $0.02 \mathrm{degree} / \mathrm{min}$. Identification of phases was achieved by comparing the diffraction patterns of the composites with the JCPDS files. The morphology and the microstructure of sintered samples were observed on polished cross sections using a scanning electron microscope (SEM) equipped with EDAX analyses system (SEM, Cambridge Instr.). Before observation and EDAX analyses, the samples were carbon

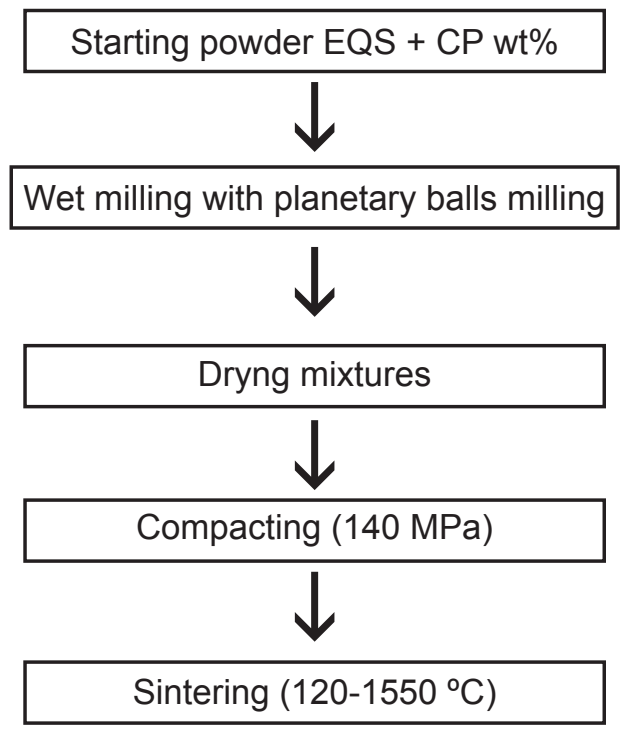

Figure 1: Schematic diagram showing the main steps of the process, used in this work.

[Figura 1: Diagrama esquemático mostrando os principais passos do processo, utilizados neste trabalho.]

coated. The starting materials were characterized by thermal analyses (DTA/TGA, Setaram 1750 Setsys) during heating from room temperature to $1500{ }^{\circ} \mathrm{C}$ at a heating rate of $5{ }^{\circ} \mathrm{C} /$ min in air. The expansion of bars (5 $\mathrm{mm} \times 5 \mathrm{~mm} \times 5 \mathrm{~mm})$ taken from compacted cylinders was characterized during heating from room temperature to $1400{ }^{\circ} \mathrm{C}$ at a heating rate of $5{ }^{\circ} \mathrm{C} / \mathrm{min}$ under air, using a DI24 dilatometer. The open porosity of sintered samples was determined using the water absorption method (ISO/TS 17892-2:2004). There were calculated using the following equation

$$
\varepsilon=(\mathrm{M} 3-\mathrm{M} 1 / \mathrm{M} 3-\mathrm{M} 2)^{*} \mathrm{~L}
$$

$\varepsilon$ total porosity, M1 sample weight m, M2 mass of the sample immersed in water, M3 mass of the sample impregnated, L density of water at the specified test temperature.

\section{RESULTS AND DISCUSSION}

Fig. 2 presents the evolution of the transformation of phases in samples containing $10 \mathrm{wt} . \% \mathrm{CP}$ as a function of the sintering temperature. It is observed that firstly there is a transformation of quartz from cristobalite at $1200{ }^{\circ} \mathrm{C}$ and wollastonite is formed. From $1250{ }^{\circ} \mathrm{C}$, tridymite appears, it is may be due to the transformation of cristobalite and the

Table I - The chemical composition of EQS, using ICP spectroscopy.

[Tabela I - Composição química da EQS usando espectroscopia ICP.]

\begin{tabular}{lllllllll}
\hline Composition & $\mathrm{SiO}_{2}$ & $\mathrm{Al}_{2} \mathrm{O}_{3}$ & $\mathrm{Fe}_{2} \mathrm{O}_{3}$ & $\mathrm{CaO}$ & $\mathrm{MgO}$ & $\mathrm{Na}_{2} \mathrm{O}$ & $\mathrm{K}_{2} \mathrm{O}$ & $\mathrm{P}_{2} \mathrm{O}_{5}$ \\
\hline EQS & 91.24 & 1.74 & 2.74 & 3.15 & 0.26 & 0.09 & 0.63 & 0 \\
$\mathrm{CP}$ & 7.27 & 1.13 & 0.31 & 48.04 & 0.23 & 1.05 & 0.78 & 40.85 \\
\hline
\end{tabular}




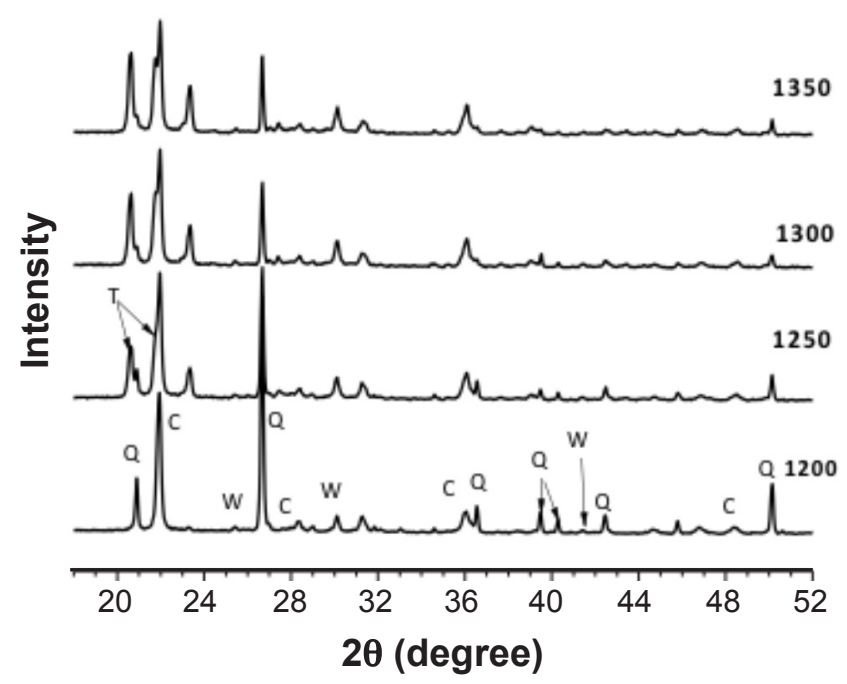

Figure 2: XRD patterns of samples of EQS $+10 \mathrm{wt} \% \mathrm{CP}$ sintered at various temperatures for $2 \mathrm{~h}$. Q (quartz); C (cristobalite); T (tridymite); W (wollastonite)..

[Figura 2: Difratogramas de raios $X$ da amostra EQS $+10 \%$ peso $C P$ sinterizadas em várias temperaturas por $2 \mathrm{~h}$. $Q$ (quartzo); $C$ (cristobalita); T (tridimita); $W$ (wollastonita).]

rate of the transformation increases with the increase in the sintering temperature. The transformation will be completed in a same time. This observation is in a good agreement with the literature. Indeed, using these raw materials may able to develop tridymite as a major phase component and becoming one of certain procedures adopted industrially for silica refractories [25].

Fig. 3 shows the effect of $\mathrm{CP}$ additions on phase transformation of samples sintered at $1300{ }^{\circ} \mathrm{C}$ for $4 \mathrm{~h}$. It is observed that the transformation is more important in the case of $30 \mathrm{wt} . \%$, tridymite appears in more quantity. So, there is a new phase $\mathrm{Ca}(\mathrm{Fe})(\mathrm{Al}) \mathrm{PO}_{4}$ which is formed by reaction between tricalcium phosphate (TCP) and oxides. This phase is detectable in the case of $30 \mathrm{wt} . \%$ due to elevated $\mathrm{CP}$ amounts. In a previous work using pure TCP with quartz, it has been found that the transformation of quartz into cristobalite was only observed without any tridymite appearance. These observations may allow believing that the TCP plays a very important role in the transformation into cristobalite and the transformation into tridymite is may be caused by impurities. This effect was observed in a work carried out on refractories containing zirconia $\left(\mathrm{ZrO}_{2}\right)$ [26]. A similar effect of the phosphate addition on transformation from $\mu$ to $\alpha$ cordierite was studied [27].

These CP additions may allow the formation of more porous volume. A typical overview of the microstructure of samples containing 10 and $30 \mathrm{wt} . \% \mathrm{CP}$ sintered at $1300{ }^{\circ} \mathrm{C}$ for $4 \mathrm{~h}$ is illustrated in Fig. 4. This micrograph shows well the distribution mod of the pore size within the matrix, the open and the communicating pores throughout the sintered samples.

A careful exam at the SEM microstructures shown in Fig 4 , one can notice that there are three distinguishable phases or grains: white grains, small white grains and grey grains.



Figure 3: XRD patterns of samples of EQS with different CP additions sintered at $1300{ }^{\circ} \mathrm{C}$ for $4 \mathrm{~h}$. Q (quartz); $\mathrm{C}$ (cristobalite); T (tridymite); W (wollastonite); ph (phosphate mineral).

[Figura 3: Difratogramas de raios $X$ das amostras EQS com adição de diferentes $C P$ sinterizadas a $1300{ }^{\circ} \mathrm{C}$ por $4 \mathrm{~h} . Q$ (quartzo); $T$ (tridimita); $W$ (wollastonita); ph (mineral fosfato).]
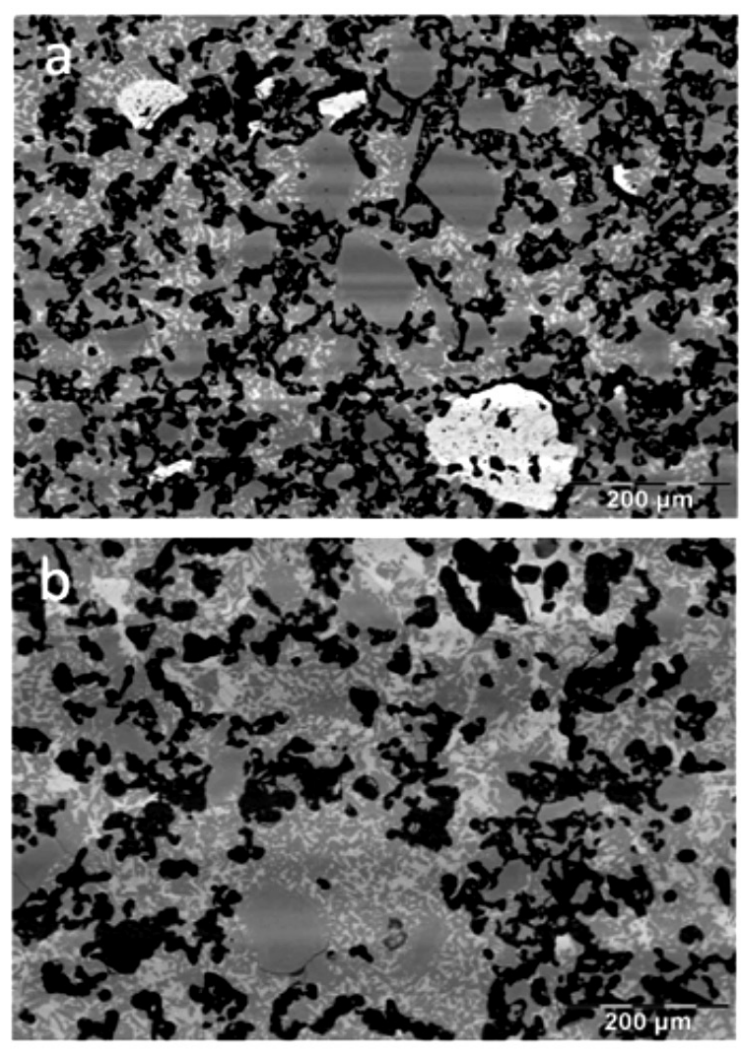

Figure 4: SEM micrographs of samples containing different CP percentages sintered at $1300{ }^{\circ} \mathrm{C}$ for $4 \mathrm{~h}$, (a) $10 \mathrm{wt} . \%$, (b) $30 \mathrm{wt} . \%$. [Figura 4: Micrografias obtidas em microscópio eletrônico de varredura das amostras contendo diferentes porcentagens de CP sinterizadas a $1300{ }^{\circ} \mathrm{C}$ por $4 \mathrm{~h}$, (a) $10 \%$ peso, (b) $30 \%$ peso.]

Local EDAX analyses were performed on each type of these three phases (Fig. 5). The grey grains (Fig. 5B) contain Si and $\mathrm{O}$. They should correspond to quartz, cristobalite and/ or tridymite. The white grains (Fig. 5C) contain $\mathrm{Ca}, \mathrm{P}$ and 


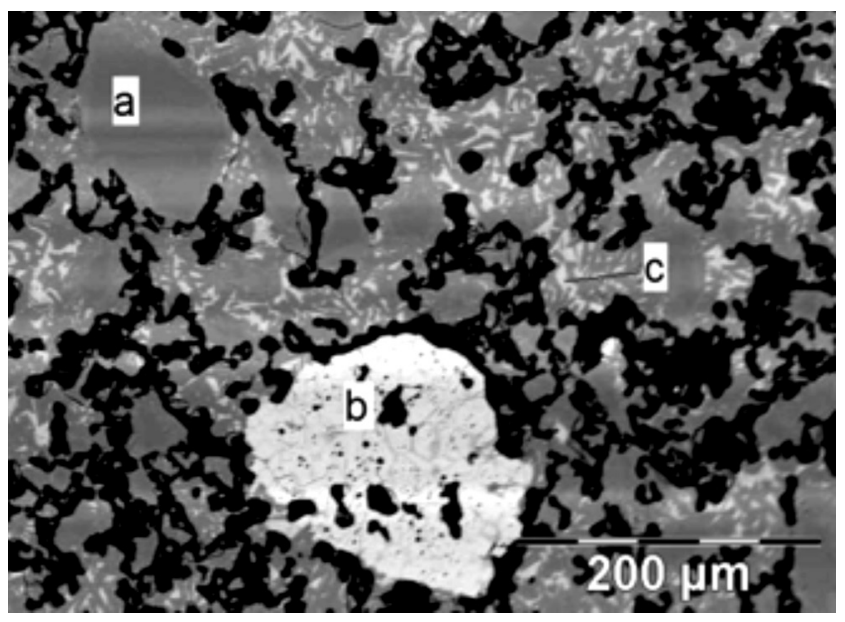

(c)

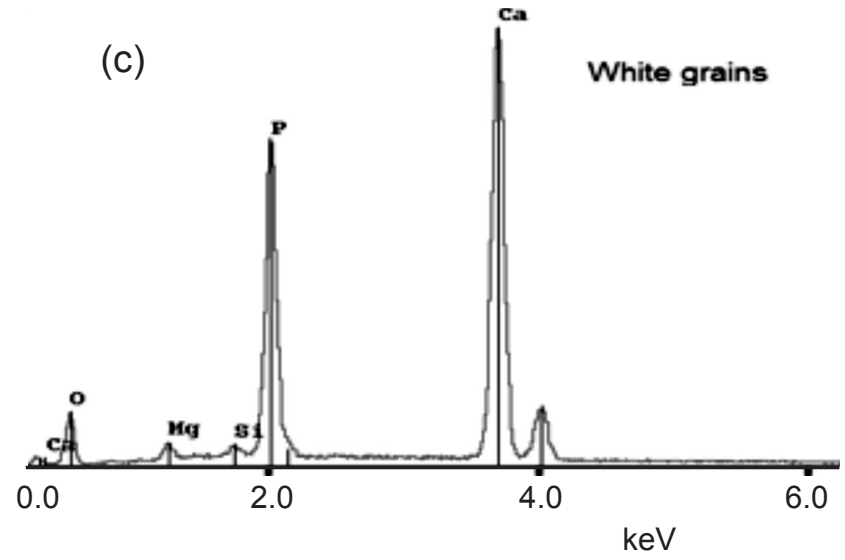

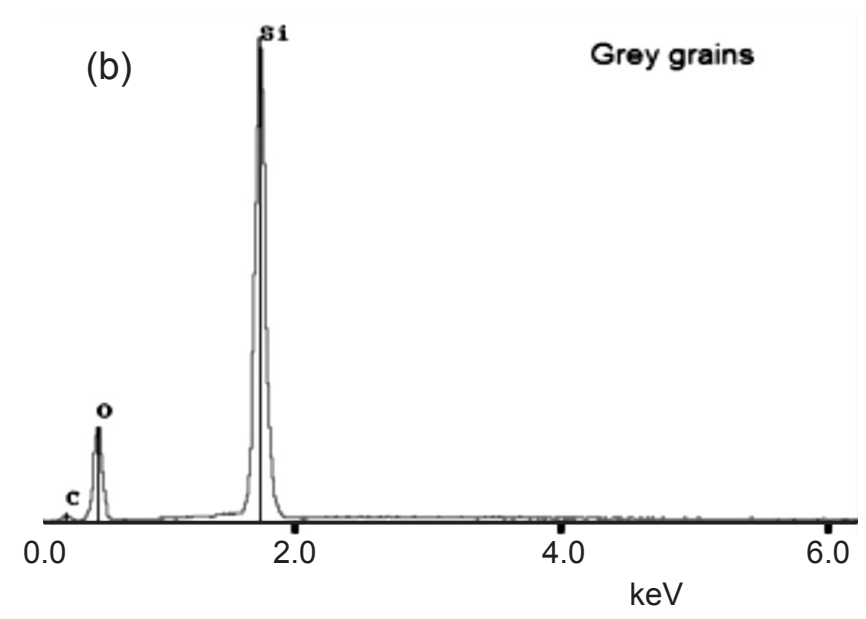

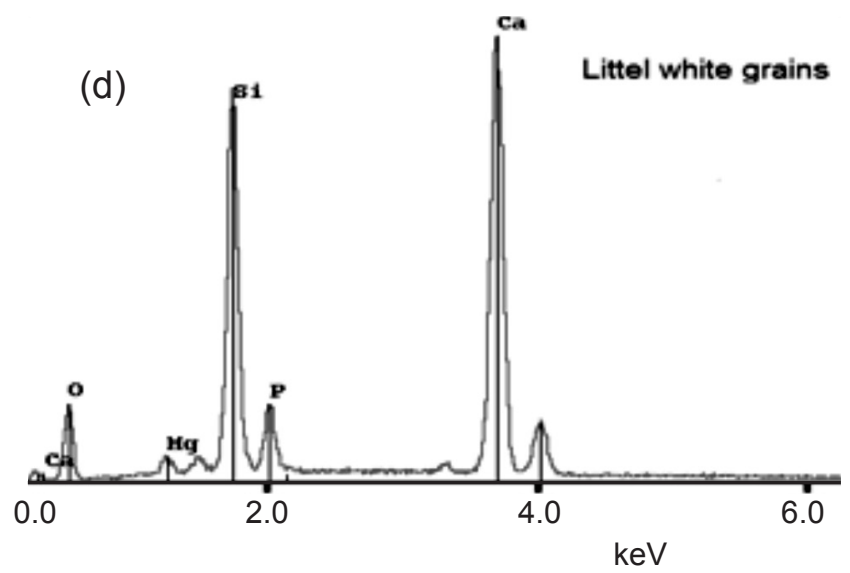

Figure 5: Local EDAX spectrum of the different phases observed in Fig. 4a for the 90 wt.\% EQS+10 wt.\% CP (A) mixtures sintered at $1300{ }^{\circ} \mathrm{C}$ for $4 \mathrm{~h}$, (B) grey grains (a), (C) white grains (b), and (D) small white grains (c).

[Figura 5: Espectro EDX das diferentes fases observadas na Fig. 4a para 90\% peso EQS + 10\% peso CP (A) misturas sinterizadas a $1300^{\circ} \mathrm{C}$ por $4 \mathrm{~h}$, (B) grãos cinza (a), (C) grãos brancos (b), e (D) pequenos grãos brancos (c).]
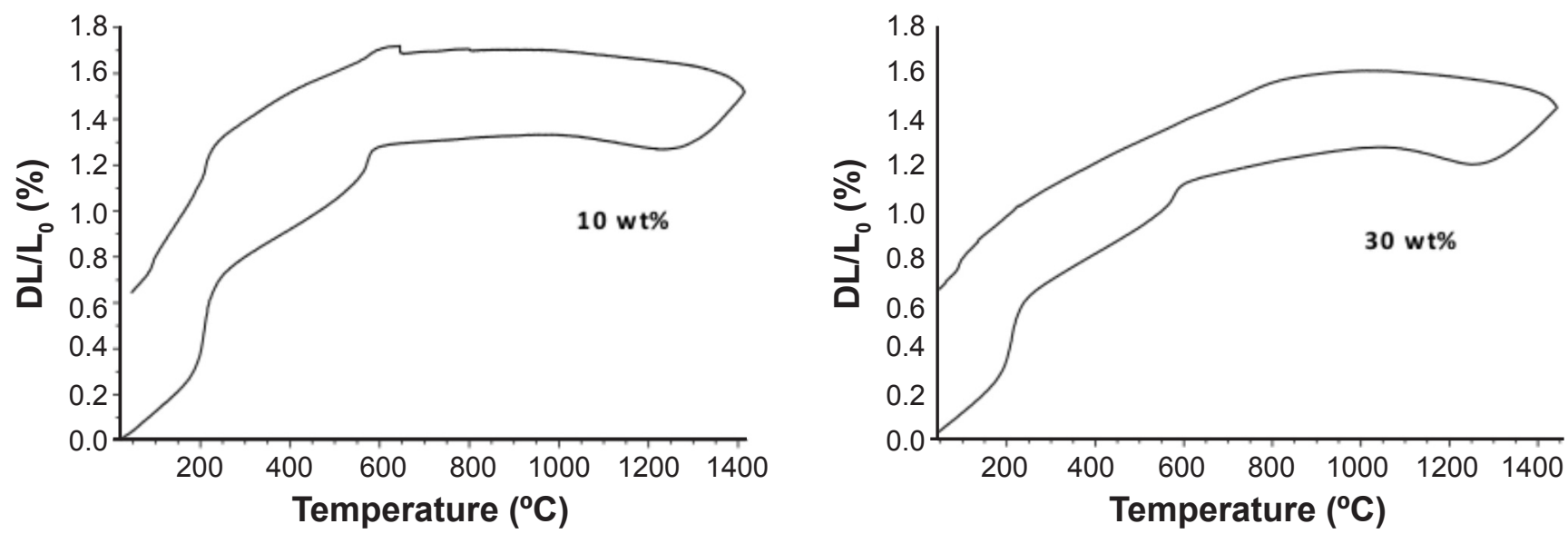

Figure 6: Thermal expansion of samples with different CP additions, sintered at $1200{ }^{\circ} \mathrm{C}$ for $2 \mathrm{~h}$, (a) $10 \mathrm{wt} . \%$, (b) $30 \mathrm{wt} . \%$.

[Figura 6: Expansão térmica das amostras com diferentes adições de CP, sinterizadas a $1200{ }^{\circ} \mathrm{C}$ por $2 \mathrm{~h}$, (a) $10 \%$ peso, (b) $30 \%$ peso.]

O with small amounts of $\mathrm{Mg}$. They should correspond to CP. Since the small white grains are distributed on the grey grains, they contain $\mathrm{Si}, \mathrm{Ca}, \mathrm{O}$ and a small P. One can suggest that there is a decomposition of the same CP into $\mathrm{CaO}$ and $\mathrm{P}_{2} \mathrm{O}_{5}$. Consequently, $\mathrm{CaO}$ reacts with $\mathrm{SiO}_{2}$ to form wollastonite and the volatilization of $\mathrm{P}_{2} \mathrm{O}_{5}$. That explains the decrease in $\mathrm{P}$ peak intensities shown in Fig. 5D. By increasing the temperature, this phenomenon continuous, thus samples sintered at $1500^{\circ} \mathrm{C}$ for $4 \mathrm{~h}$ do not contain $\mathrm{CP}$ grains. They are formed by two types of grains. The first 


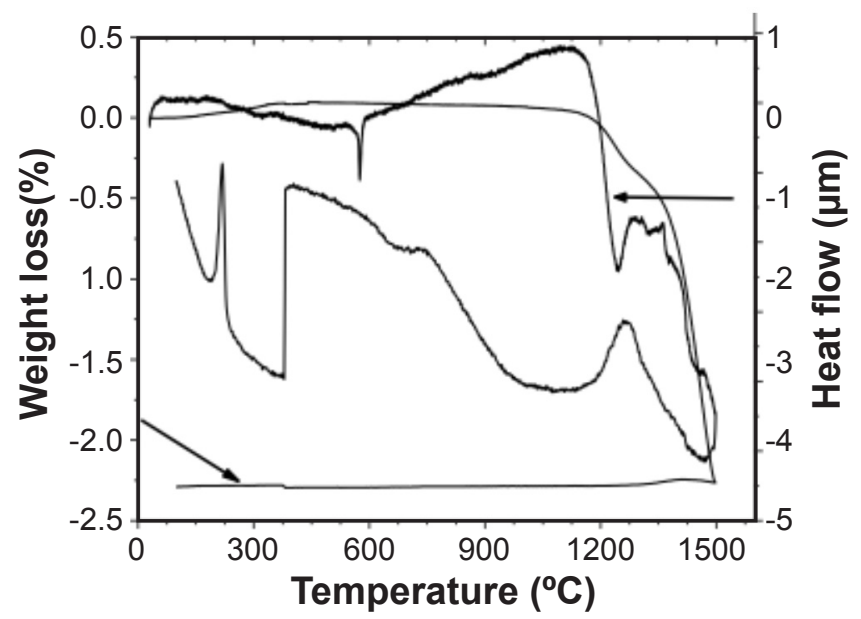

Figure 7: DTA and TG curves of samples containing $30 \mathrm{wt} \% \mathrm{CP}$. [Figura 7: Curvas ATD e TG das amostras contendo 30\% peso CP.]

type contains $\mathrm{Si}$ and $\mathrm{O}$ which constitute tridymite and/or cristobalite phases. However, the others contain $\mathrm{Si}, \mathrm{Ca}, \mathrm{O}$ and a few of $\mathrm{P}$ which may correspond to wollastonite and a composite of phosphate (Fig. 3).

Fig. 6 shows the expansion curve of samples sintered at $1200^{\circ} \mathrm{C}$ for $2 \mathrm{~h}$. It is observed that at $220^{\circ} \mathrm{C}$ expansion results from transformation of $\alpha$ cristobalite to $\beta$ cristobalite, whereas at $567{ }^{\circ} \mathrm{C}$ the expansions may be due to the transformation of residual $\alpha$ quartz to $\beta$ quartz. Afterwards, the transformation of the residual quartz to critobalite and tridymite continues between 1200 and $1400^{\circ} \mathrm{C}$, which explains the expansion in this range. During cooling, expansion is very low from 600 to $1400{ }^{\circ} \mathrm{C}$ in the case of $10 \mathrm{wt} . \%$. In the case of $30 \mathrm{wt} . \%$, the transformation is completed and there is no a reversible transformation from $\beta$ to $\alpha$ and expansion is very low in the range between 800 and $1400{ }^{\circ} \mathrm{C}$.

The thermal behavior of EQS + $30 \mathrm{wt} . \%$ in terms of DTA and TG are illustrated in Fig 7. There is no loss in weight observed until $1200{ }^{\circ} \mathrm{C}$. Subsequently, a loss starts within a small amount between 1200 to $1400{ }^{\circ} \mathrm{C}$ and increases rapidly. This increase may be due to a decomposition of a small amount of $\mathrm{CP}$ and $\mathrm{P}_{2} \mathrm{O}_{5}$ volatilization. This result is also confirmed by EDX analyses shown in Fig. 5. In fact, this loss explains an increase in a total porosity in samples sintered at a temperature above $1400{ }^{\circ} \mathrm{C}$. A similar observation is reported [28]. The DTA curve shows a sharp endothermic peak at $570{ }^{\circ} \mathrm{C}$ on heating step, attributed to the $\alpha-\beta$ quartz transformation and an exothermic peak at $220{ }^{\circ} \mathrm{C}$ on cooling step, attributed to the $\beta-\alpha$ cristobalite transformation. At 1240 and $1260{ }^{\circ} \mathrm{C}$ there are two peaks; one endothermic and other exothermic, respectively. These two peaks may be attributed to the transformation of tricalcium phosphate (TCP) ( $\beta$ to $\alpha$ on heating step and $\alpha$ to $\beta$ on cooling step.

The total porosity as function of sintering temperature is shown in Fig. 8. In these three cases, the total porosity decreases slightly in the range between 1200 and $1400{ }^{\circ} \mathrm{C}$. Afterwards, it increases slightly up to $1550^{\circ} \mathrm{C}$.

For example, the porosity ratio values are ranged

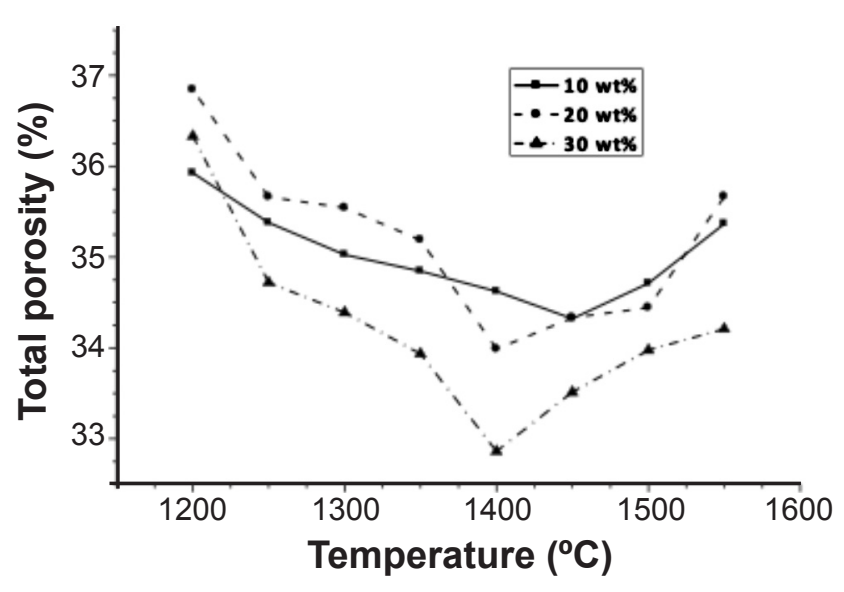

Figure 8: Total porosity of the samples with different $\mathrm{CP}$ additions, sintered at different temperatures for $2 \mathrm{~h}$.

[Figura 8: Porosidade total das amostras com diferentes adições de CP, sinterizadas em diferentes temperaturas por 2 h.]

between 37 and $33 \%$ for the three sets of samples. This decrease is closely related to the sintering phenomena whereas the increase is may be due to decomposition of $\mathrm{CP}$ and the $\mathrm{P}_{2} \mathrm{O}_{5}$ vaporization. Moreover, the same porosity ratio was obtained [29] using quartz and zeolite without any presintering.

\section{CONCLUSIONS}

From the X-ray diffraction analyses it can be concluded that the $\mathrm{CP}$ addition plays a very important role as a mineralizer that promotes transformation and stabilization phase. It acts as a binder and allows achieving acceptable sintered samples within a considerably higher porosity ratio. It is believed that according to the currently chemical mapping there is a reaction between the $\mathrm{CP}$ and silica to form a composite which contains $\mathrm{Si}, \mathrm{P}, \mathrm{Ca}$ and $\mathrm{O}$.

\section{REFERENCES}

[1] J. Wart, Le silicium dans la nature, chimie minérale, tome 2, Éd. Masson, France (1968) pp. 23-24.

[2] J. H. Chesters, "Refractories production and properties", Iron \& Steel Inst., London, UK (1973) pp. 67-71; 98.

[3] A. Harabi, S. Achour, J. Mater. Sci. Lett. 18 (1999) 955.

[4] R. Boudchicha, S. Achour, A. Harabi, J. Mater. Sci. Lett. 20 (2001) 15.

[5] A. Mecif, J. Soro, J. P. Bonnet, A. Harabi, J. Am. Ceram. Soc. 93 (2010) 1306.

[6] S. Achour, A. Harabi, N. Tabet, Mater. Sci. Eng. B 42 (1996) 289.

[7] O. Toumiat, S. Achour, A. Harabi, N. Tabet, M. Boumaour, M. Maallemi, Nanotechnology 17 (2006) 658.

[8] O. Bourbia, S. Achour, N. Tabet, M. Parlinska, A. Harabi, Thin Solid Films 515 (2007) 6758.

[9] A. Guechi, S. Ahour, A. Harabi, Key Eng. Mater. 264268 (2004) 257.

[10] F. Bouzerara, A. Harabi, S. Achour, A. Labrot, J. Eur. 
Ceram. Soc. 26 (2006) 1663.

[11] A. Harabi, F. Bouzerara, S. Condom, Des. Water Treat. 6 (2009) 222.

[12] B. Boudaira, A. Harabi, F. Bouzera ra, S. Condom, Des. Water Treat. 9 (2009)142.

[13] F. Bouzerara, A. Harabi, S. Condom, Des. Water Treat. 12 (2009) 415.

[14] A. Harabi, A. Guechi, S. Condom, Proc. Eng. 33 (2012) 220.

[15] F. Bouzerara, A. Harabi, B. Ghouil, N. Medjemem, B. Boudaira, S. Condom, Proc. Eng. 33 (2012) 78.

[16] A. Harabi, F. Zenikheri, B. Boudaira, F. Bouzerara, A. Guechi, L. Foughali, J. Eur. Ceram. Soc. 34 (2014) 1329.

[17] F. Z. Mezahi, H. Oudadesse, A. Harabi, A. LucasGirot, Y. Le Gal, H. Chaair, G. Cathelineau, J. Therm. Anal. Calorim. 95 (2009) 21.

[18] F. Z. Mezahi, H. Oudadesse, A. Harabi, A. Lucas-Girot, Int. J. Appl. Ceram. Technol. 9 (2012) 529.

[19] A. Harabi, S. Chehlatt, J. Therm. Anal. Calorim. 111 (2013) 203.

[20] A. Harabi, S. Zouai, J. Appl. Ceram. Technol. 11 (2014) 31.

[21] A. Harabi, D. Belamri, N. Karboua, F. Z. Mezahi, J.
Therm. Anal. Calorim. 104 (2011) 283.

[22] A. Lucas - Girot , F. Z. Mezahi , M. Mami, H. Oudadesse, A. Harabi, M. Le Floch, J. Non-Crystalline Solids 357 (2011) 3322.

[23] F. Z. Mezahi, A. Lucas - Girot, H. Oudadesse, A. Harabi, J. Non-Crystalline Solids 361 (2013) 111.

[24] F. Z. Mezahi, A. Harabi, S. Zouai, S. Achour, D. Bernache-Assollant, Mater. Sci. Forum 492-493 (2005) 241. [25] W. N. dos Santos, J. B. Baldo, R. Taylor, Mater. Res. Bull. 35 (2000) 2091.

[26] E. Volceanove, M. Georgescu, F. Mihalache, A. Volceanov, M. A. Pantea, A. Apstol, "Zirconium phosphates bonded refractory composites", $6^{\text {th }}$ Conf. Eur. Ceram. Soc. 2 (1999) 179-180.

[27] S. Met, J. Yang, J. M. Ferreira, "The effect of $\mathrm{P}_{2} \mathrm{O}_{5}$ additive on the transformation of cordierite in sol-gelderived powders", $6^{\text {th }}$ Conf. Eur. Ceram. Soc. 2 (1999) 125 126.

[28] M. Rivenet, O. Coisin, J. C. Boivin, F. Abraham, N. Ruchaud, P. Hubert, J. Eur. Ceram. Soc. 20 (2000) 1169. [29] O. San, S. Abali, C. Hosten, Ceram. Int. 29, 8 (2003) 927.

(Rec. 06/08/2014, Ac. 07/10/2014) 